\title{
HIGH DOSE FENTANYL ANAESTHESIA WITH OXYGEN FOR AORTO-CORONARY BYPASS SURGERY
}

\author{
L. Quintin, D.G. Whalley, J.E. Wynands, J.E. Morin and J. Burke
}

\begin{abstract}
Ten patients were anaesthetized with 100 per cent oxygen and fentanyl $100 \mu \mathrm{g} \cdot \mathrm{kg}^{-1}$ for aorto-coronary bypass surgery and studied during induction of anaesthesia and initial surgical stimulation. All patients were taking propranolol and nitrates preoperatively. The patients were pre-medicated with diazcpam $0.15 \mathrm{mg} \cdot \mathrm{kg}^{-1}$ by mouth and morphine $0.15 \mathrm{mg} \cdot \mathrm{kg}^{-1}$ and scopolamine $0.4 \mathrm{mg}$ intramuscularly. Intravenous, arterial and Swan-Ganz catheters were inserted under local anaesthesia, after which control measurements were taken of heart rate, systolic blood pressure, pulmonary capillary wedge pressure, stroke index, cardiac index, left ventricular stroke work index, systemic vascular resistance, rate pressure product, triple index, $\mathrm{Pa}_{\mathrm{O}_{2}}$ and $\mathrm{Pa}_{\mathrm{CO}_{2}}$.

Observations were repeated after fentanyl $50 \mu \mathrm{g} \cdot \mathrm{kg}^{-1}$ and pancuronium $0.1 \mathrm{mg} \cdot \mathrm{kg}^{-1}$, tracheal intubation, a further $50 \mu \mathrm{g} \cdot \mathrm{kg}^{-1}$ of fentanyl, skin incision and sternotomy.

No significant changes from control values were seen in heart rate, central venous pressure or systemic vascular resistance. Systolic blood pressure and left ventricular stroke work index decreased significantly after fentanyl $50 \mu \mathrm{g} \cdot \mathrm{kg}^{-1}$ left ventricular stroke work index staying below control for the remainder of the study. Pulmonary capillary wedge pressure, triple index and $\mathrm{Pa}_{\mathrm{CO}_{2}}$ decreased significantly after fentanyl $100 \mu \mathrm{g} \cdot \mathrm{kg}^{-1}$ skin incision and sternotomy. Significant decreases were noted in rate pressure product after skin incision, stroke index after sternotomy and cardiac index after both skin incision and sternotomy.

Oxygen and fentanyl $100 \mu \mathrm{g} \cdot \mathrm{kg}^{-1}$ provided stable indices of myocardial oxygen demand during induction, tracheal intubation and initial surgical stimulation in patients undergoing aorto-coronary bypass surgery.
\end{abstract}

Key Words: Anaesthetics, InTRavenous, fentanyl; Surgery, cardiac, aortocoronary bypass.

OXYGEN AND HIGH DOSE of fentanyl has been adopted in many centres after reports that this technique provides stable haemodynamic conditions during valvular' and coronary artery surgery. ${ }^{2}$ It has been suggested that this technique modifies the endocrine response to anaesthesia and surgical stimulation as evidenced by the absence of increases of plasma anti-diuretic hormone, ${ }^{2}$ cortisol and catecholamines ${ }^{3}$ in the prebypass period.

However, some observers using this anaesthesia have noted tachycardia and hypertension after intubation and surgical stimulation in both coronary ${ }^{4}$ and general surgery. ${ }^{5}$ Furthermore,

L. Quintin, M.Sc., M.D., Resident Anaesthetist; D.G. Whalley, M.B., Ch.B., F.F.A.R.C.S., F.R.C.P.(C), Assistant Anaesthetist; J.E. Wynands, M.D., F.R.C.P.(C), Senior Anaesthetist; J.E. Morin, M.D., F.R.C.S.(C), Chief, Cardiovascular and Thoracic Surgery Service; J. Burke, Perfusionist. Royal Victoria Hospital, Montreal, P.Q.

Address for reprints: J.E. Wynands, M.D., Department of Anaesthesia, Royal Victoria Hospital, Montreal, Quebec H3A 1A1.

Canad. Anaesth. Soc. J., vol. 28, no. 4, July 1981 truncal rigidity associated with possible hypoventilation $^{6}$ is a frequent event necessitating the prompt administration of muscle relaxant regardless of the patient's conscious state. ${ }^{4}$ Perioperative awareness similar to that reported with oxygen-high dose morphine anaesthesia ${ }^{7}$ has been both denied ${ }^{1,2,8}$ and confirmed. ${ }^{5}$ Another potentially troublesome side effect of the technique is prolonged postoperative respiratory depression. $^{2,5,8}$

The haemodynamic responses to induction of anaesthesia and to surgical stimulation in patients anaesthetized with high doses of fentanyl with oxygen are probably dependent upon the total dose of fentanyl administered, ${ }^{2,4,8}$ the speed of administration of the drug, and the patient's drug history, particularly the use of propranolol in the immediate preoperative period..$^{9,10}$

We wished to determine in patients maintained on propranolol to the time of surgery, whether fentanyl $50 \mu \mathrm{g} \cdot \mathrm{kg}^{-1}$ given before tracheal intubation followed by a further $50 \mu \mathrm{g} \cdot \mathrm{kg}^{-1}$ before skin incision would produce stable haemodynamic 314 
TABLE I

Patient Data

Number of patients $=10$

\begin{tabular}{|c|c|c|}
\hline Age (years) & mean $\pm \mathrm{sd}$ & $59.9 \pm 6.4$ \\
\hline Sex & $\begin{array}{l}\text { female } \\
\text { male }\end{array}$ & $\begin{array}{l}2 \\
8\end{array}$ \\
\hline Height (m) & mean $\pm \mathrm{sd}$ & $1.68 \pm 0.05$ \\
\hline Weight (kg) & mean \pm sd & $73.6 \pm 10.4$ \\
\hline Body surface area $\left(\mathrm{m}^{2}\right)$ & mean \pm sd & $1.83 \pm 0.09$ \\
\hline Unstable angina & & 5 \\
\hline Previous myocardial infarction & & 3 \\
\hline \multirow[t]{3}{*}{ NYHA classification } & II & 1 \\
\hline & III & 4 \\
\hline & IV & 5 \\
\hline \multirow[t]{4}{*}{ Left ventricular function } & normal & 5 \\
\hline & mild impairment & 1 \\
\hline & moderate impairment & 1 \\
\hline & severe impairment & 3 \\
\hline Daily propranolol dose (mg) & mean \pm sd & $232 \pm 165$ \\
\hline Number of $A C B P$ per patient & mean \pm sd & $3.2 \pm 1.1$ \\
\hline
\end{tabular}

NYHA: New York Heart Association. Mild impairment: one area of dyskinesia or hypokinesia or akinesia. Moderate impairment: two areas of dyskinesia or hypokinesia or akinesia. Severe impairment: three or more. Unstable angina defined as: 1) New onset angina or evolving angina not responding to medical treatment. 2) Angina at rest. 3) Preinfarction. 4) Pre-extension post-infarction.

parameters during the induction of anaesthesia and early surgical stimulation.

\section{METHODS}

This investigation was approved by the Ethics Committee for Clinical Study of the Royal Victoria Hospital. Ten patients presenting for aortocoronary bypass surgery were studied (Table I). Four patients were considered to have poorly controlled hypertension (systolic blood pressure over $21.3 \mathrm{kPa}$ (160torr) or diastolic blood pressure over $12 \mathrm{kPa}(90$ torr)). Five patients, three with a history of myocardial infarction, had impairment of left ventricular function as demonstrated by ventriculography.

All patients were receiving propranolol and nitrate preparations up to and including the morning of the operation. One patient, being treated with digoxin and furosemide, received his last dose of both drugs the day before operation. A detailed explanation of the anaesthetic and surgical procedure was given to each patient during the preoperative visit. Premedication consisted of flurazepam $30 \mathrm{mg}$ as night sedation, and diazepam $0.15 \mathrm{mg} \cdot \mathrm{kg}^{-1}$ by mouth, morphine $0.15 \mathrm{mg} \cdot \mathrm{kg}^{-1}$ and scopolamine $0.4 \mathrm{mg}$ intramuscularly 60 to 90 minutes before operation.

Upon arrival in the operating room, a five lead electrocardiograph was attached to the patient and lead VS was monitored for the duration of the study." A 16 gauge intravenous catheter, 18 gauge intra-arterial and $7 \mathrm{Fr}$ thermodilution Swan-Ganz catheters were subsequently inserted under local anaesthesia.

One hundred per cent oxygen was then administered to the patient through a face mask, followed by an injection of pancuronium $1 \mathrm{mg}$ in an attempt to retard the onset of truncal rigidity. ${ }^{6}$ The fentanyl infusion $\left(50 \mu \mathrm{g} \cdot \mathrm{ml}^{-1}\right)$ was started at a rate of 400 to $600 \mu \mathrm{g} \cdot \mathrm{min}^{-1}$ and continued until an initial dose of $50 \mu \mathrm{g} \cdot \mathrm{kg}^{-1}$ had been given. Pancuronium $0.1 \mathrm{mg} \cdot \mathrm{kg}^{-1}$ was injected when the patient failed to respond to verbal command. Ventilation was assisted initially and then controlled manually before tracheal intubation, which was done without topical anaesthesia after fentanyl had been infused and the patient was 95 per cent or more paralyzed as judged by nerve stimulation. After intubation, the patient was ventilated with 100 per cent oxygen using a Bain circuit $^{12}$ and an Airshield Ventimeter Ventilator with the appropriate gas flow settings to achieve normocapnia.

A further $50 \mu \mathrm{g} \cdot \mathrm{kg}^{-1}$ of fentanyl was then infused at a similar rate. The patient thus received a total of $100 \mu \mathrm{g} \cdot \mathrm{kg}^{-1}$ of fentanyl before skin incision. No drugs other than oxygen, fentanyl and pancuronium were used during the study. The mean volume of sodium chloride 0.9 
TABLE II

AbBreviations and Formulae

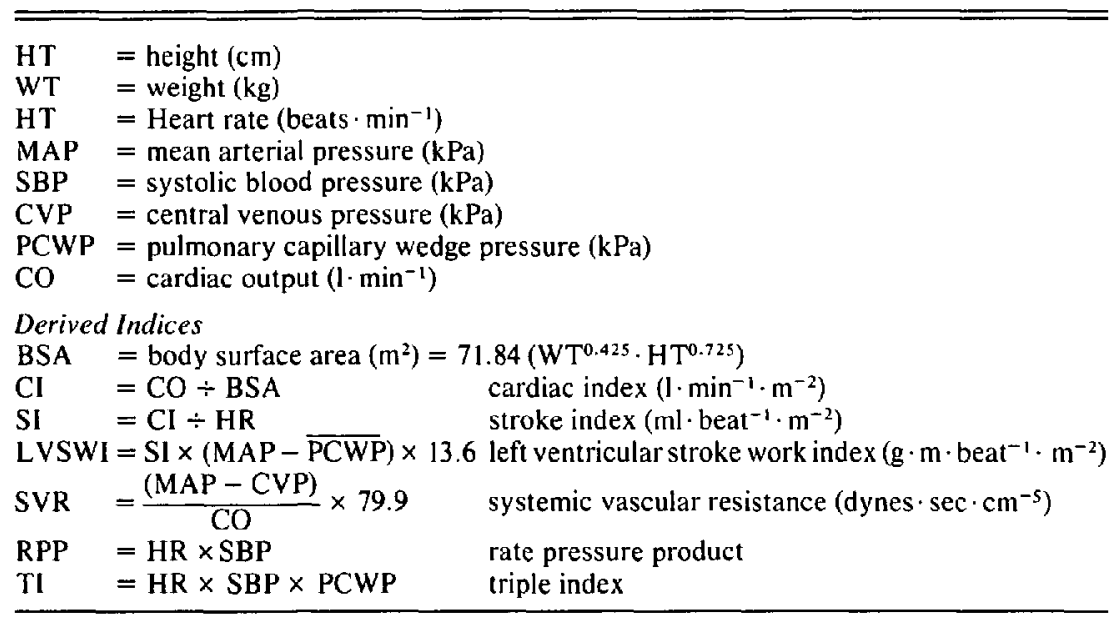

per cent administered to each patient for the duration of the study was $0.806 \pm 0.244$ (sd) litres.

Monitoring equipment consisted of Bentley Trantec transducers, General Electric Four Traces monitor, and Edwards Laboratories Cardiac Output Computer model 9520. Blood gases were analyzed on a Corning apparatus model 175 with automatic calibration.

Control arterial blood gases and haemodynamic data were collected immediately after all catheters had been inserted. Further observations were made after infusion of fentanyl $50 \mu \mathrm{g} \cdot \mathrm{kg}^{-1}$, tracheal intubation and initiation of intermittent positive pressure ventilation, a further $50 \mu \mathrm{g} \cdot \mathrm{kg}^{-1}$ of fentanyl, skin incision, and sternotomy. The central venous pressure and pulmonary capillary wedge pressure were taken at the end of the expiration without disconnecting the patient from the ventilator. ${ }^{13}$

Inferred data were obtained by the use of a Texas instrument TI 59 programmable calculator using formulae in Table II.

Statistical analysis was made by Student's " $t$ " test paired to control. Values of " $p$ " less than 0.05 were considered significant.

\section{Results}

The data obtained during the study are expressed in Table III and shown in Figure 1.

No significant changes from control were observed in heart rate, central venous pressure and systemic vascular resistances, throughout the study. Significant decreases from control were seen in systolic blood pressure and left ventric- ular stroke work index after fentanyl $50 \mu \mathrm{g} \cdot \mathrm{kg}^{-1}$ and pancuronium $0.1 \mathrm{mg} \cdot \mathrm{kg}^{-1}$. Left ventricular stroke work index stayed below control values for the remainder of the study. Pulmonary capillary wedge pressure, triple index and $\mathrm{Pa}_{\mathrm{CO}_{2}}$ decreased significantly after completion of the total dose of fentanyl, remaining significantly lower than control after both skin incision and sternotomy. Significant decreases were noted in rate pressure product after skin incision, stroke index after sternotomy and cardiac index after both skin incision and sternotomy.

None of the patients showed any evidence of ischaemia in lead V5 throughout the investiga-
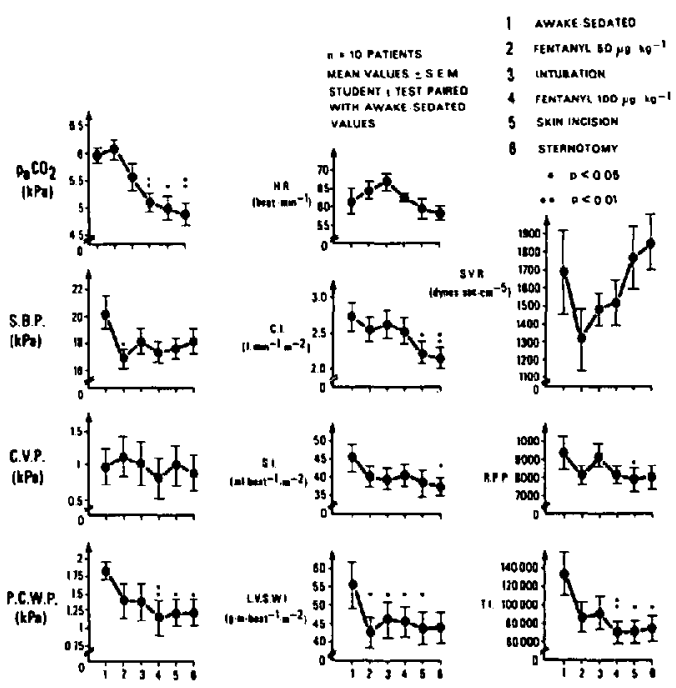

Figure 1 Haemodynamic data and $\mathrm{Pa}_{\mathrm{CO}_{2}}$ values during high dose fentanyl anaesthesia with oxygen for coronary artery surgery. 
TABLE III

Haemodynamic Data and Pa $\mathrm{CO}_{2}$ Values During High Dose Fentanyl and Oxygen Anaesthesia for Coronary Artery Surgery

\begin{tabular}{|c|c|c|c|c|c|c|}
\hline & $\begin{array}{l}\text { Awake } \\
\text { Sedated } \\
\text { (Control) }\end{array}$ & $\begin{array}{c}\text { Fentanyl } \\
50 \mu \mathrm{g} \cdot \mathrm{kg}^{-1}\end{array}$ & $\begin{array}{c}\text { After } \\
\text { Intubation }\end{array}$ & $\begin{array}{c}\text { Fentanyl } \\
100 \mu \mathrm{g} \cdot \mathrm{kg}^{-1}\end{array}$ & $\begin{array}{l}\text { After Skin } \\
\text { Incision }\end{array}$ & $\begin{array}{c}\text { After } \\
\text { Sternotomy }\end{array}$ \\
\hline $\begin{array}{l}\text { HR (beat } \cdot \min ^{-1} \text { ) } \\
\text { sd } \\
\text { per cent change } \\
\text { control values }\end{array}$ & $\begin{array}{r}61.3 \\
\pm 8.5 \\
-\end{array}$ & $\begin{array}{l}64.1 \\
\pm 5.6 \\
+4\end{array}$ & $\begin{array}{l}66.8 \\
\pm 7 \\
+9\end{array}$ & $\begin{array}{l}62.4 \\
\pm 3 \\
+2\end{array}$ & $\begin{array}{l}59.4 \\
\pm 7 \\
-3\end{array}$ & $\begin{array}{l}58.2 \\
\pm 6 \\
-5\end{array}$ \\
\hline $\begin{array}{c}\text { SBP (kPa) } \\
\text { sd } \\
\text { per cent change }\end{array}$ & $\begin{array}{l}20.186 \\
\pm 4.637 \\
-\end{array}$ & $\begin{array}{c}16.77 \\
\pm 2.358 \\
-17 \\
*\end{array}$ & $\begin{array}{r}18.133 \\
\pm 2.972 \\
-10\end{array}$ & $\begin{array}{l}17.4 \\
\pm 2.398 \\
-14\end{array}$ & $\begin{aligned} & 17.64 \\
& \pm 2.717 \\
- & 13\end{aligned}$ & $\begin{array}{l}18.146 \\
\pm 3.028 \\
-10\end{array}$ \\
\hline $\begin{array}{c}\text { CVP (kPa) } \\
\text { sd } \\
\text { per cent change }\end{array}$ & $\begin{array}{r}0.966 \\
\pm 0.878 \\
-\end{array}$ & $\begin{array}{r}1.104 \\
\pm 0.942 \\
+14\end{array}$ & $\begin{aligned} & 1.009 \\
\pm & 0.992 \\
+ & 4\end{aligned}$ & $\begin{array}{r}0.802 \\
\pm 0.905 \\
-17\end{array}$ & $\begin{aligned} & 0.986 \\
\pm & 0.927 \\
+ & 2\end{aligned}$ & $\begin{aligned} & 0.873 \\
&+0.834 \\
&-10\end{aligned}$ \\
\hline $\begin{array}{c}\text { PCWP }(\mathrm{kPa}) \\
\text { sd } \\
\text { per cent change }\end{array}$ & $\begin{array}{r}1.833 \\
\pm 0.421 \\
-\end{array}$ & $\begin{array}{l}1.4 \\
\pm 0.814 \\
-24\end{array}$ & $\begin{aligned} & 1.38 \\
\pm & 0.842 \\
-25 & \end{aligned}$ & $\begin{array}{c}1.16 \\
\pm 0.674 \\
-27 \\
* *\end{array}$ & $\begin{array}{c}1.24 \\
\pm 0.619 \\
-23 \\
*\end{array}$ & $\begin{array}{c}1.23 \\
\pm 0.655 \\
-23 \\
*\end{array}$ \\
\hline $\begin{array}{c}\text { CI }\left(1 \cdot \min ^{-1} \cdot \mathbf{m}^{-2}\right) \\
\text { sd } \\
\text { per cent change }\end{array}$ & $\begin{array}{r}2.72 \\
\pm 0.62 \\
-\end{array}$ & $\begin{array}{l}2.55 \\
\pm 0.53 \\
-7\end{array}$ & $\begin{aligned} & 2.63 \\
& \pm 0.64 \\
&-4\end{aligned}$ & $\begin{array}{l}2.52 \\
\pm 0.58 \\
-8\end{array}$ & $\begin{array}{c}2.23 \\
\pm 0.51 \\
-18 \\
*\end{array}$ & $\begin{array}{r}2.16 \\
\pm 0.40 \\
-21 \\
* *\end{array}$ \\
\hline $\begin{array}{c}\mathrm{SI}\left(\mathrm{ml} \cdot \text { beat }^{-1} \cdot \mathrm{m}^{-2}\right) \\
\mathrm{sd} \\
\text { per cent change }\end{array}$ & $\begin{array}{r}45.21 \\
\pm 11.85 \\
-\end{array}$ & $\begin{array}{l}40.17 \\
\pm 9.17 \\
-11\end{array}$ & $\begin{array}{l}39.46 \\
\pm 9.01 \\
-13\end{array}$ & $\begin{array}{r}40.49 \\
\pm 8.73 \\
-11\end{array}$ & $\begin{array}{l}38.38 \\
\pm 11.33 \\
-15\end{array}$ & $\begin{array}{c}37.53 \\
\pm 8.16 \\
-17 \\
*\end{array}$ \\
\hline $\begin{array}{c}\text { LVSWI }\left(\mathrm{g} \cdot \mathrm{m} \cdot \text { beat }^{-1} \cdot \mathrm{m}^{-2}\right) \\
\text { sd } \\
\text { per cent change }\end{array}$ & $\begin{array}{r}55.31 \\
\pm 19.87 \\
-\end{array}$ & $\begin{aligned} & 42.41 \\
\pm & 12.05 \\
- & 24 \\
& *\end{aligned}$ & $\begin{aligned} & 45.83 \\
& \pm 14.79 \\
&-17 \\
& *\end{aligned}$ & $\begin{aligned} & 45.26 \\
& \pm 13.41 \\
&- 18 \\
& *\end{aligned}$ & $\begin{aligned} & 43.61 \\
\pm & 13.92 \\
- & 21 \\
& *\end{aligned}$ & $\begin{aligned} & 43.92 \\
+ & 13.1 \\
- & 21\end{aligned}$ \\
\hline $\begin{array}{l}\text { SVR (dynes } \cdot \mathrm{sec} \cdot \mathrm{cm}^{-5} \text { ) } \\
\text { sd } \\
\text { per cent change }\end{array}$ & $\begin{array}{r}1681 \\
\pm 742 \\
-\end{array}$ & $\begin{array}{r}1308 \\
\pm 554 \\
-22\end{array}$ & $\begin{array}{r}1482 \\
\pm 281 \\
-12\end{array}$ & $\begin{array}{r}1512 \\
\pm 394 \\
-10\end{array}$ & $\begin{array}{r}1764 \\
\pm 540 \\
+5\end{array}$ & $\begin{array}{r}1843 \\
\pm 488 \\
+10\end{array}$ \\
\hline $\begin{array}{c}\text { RPP } \\
\text { sd } \\
\text { per cent change }\end{array}$ & $\begin{array}{r}9348 \\
\pm 2757 \\
-\end{array}$ & $\begin{array}{r}8074 \\
\pm 1415 \\
-14\end{array}$ & $\begin{array}{r}9140 \\
+2114 \\
-3\end{array}$ & $\begin{array}{r}8167 \\
+1365 \\
-13\end{array}$ & $\begin{array}{r}7908 \\
+1952 \\
-16 \\
*\end{array}$ & $\begin{array}{r}7978 \\
\pm 1949 \\
-15\end{array}$ \\
\hline $\begin{array}{c}\text { TI } \\
\text { Sd } \\
\text { per cent change }\end{array}$ & $\begin{array}{c}133560 \\
+77371 \\
-\end{array}$ & $\begin{array}{r}84964 \\
+56152 \\
-27\end{array}$ & $\begin{array}{r}91057 \\
+58540 \\
-22\end{array}$ & $\begin{array}{r}69557 \\
+39185 \\
-48 \\
* *\end{array}$ & $\begin{array}{r}72246 \\
\pm 38330 \\
-46 \\
*\end{array}$ & $\begin{array}{r}73226 \\
\pm 43840 \\
-45 \\
*\end{array}$ \\
\hline $\begin{array}{c}\mathrm{Pa}_{\mathrm{CO}_{2}}(\mathrm{kPa}) \\
\mathrm{sd} \\
\text { per cent change }\end{array}$ & $\begin{array}{c}5.96 \\
\pm 0.461\end{array}$ & 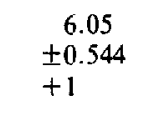 & $\begin{aligned} & 5.55 \\
& \pm 0.78 \\
&-7\end{aligned}$ & $\begin{array}{c}5.06 \\
\pm 0.798 \\
-16 \\
* *\end{array}$ & $\begin{aligned} & 4.986 \\
\pm & 0.702 \\
-17 & \end{aligned}$ & $\begin{array}{c}4.88 \\
\pm 0.662 \\
-18 \\
* *\end{array}$ \\
\hline
\end{tabular}

Values are expressed as mean \pm standard deviation and per cent changes from control values. ${ }^{*} p<0.05$ (paired Student's " $t$ " test with control values).

$* * p<0.01$.

tion. All patients had a $\mathrm{Pa}_{\mathrm{O}}$ greater than $100 \mathrm{kPa}$ (300 torr) for the duration of the study and the highest $\mathrm{Pa}_{\mathrm{CO}_{2}}$ encountered was $6.6 \mathrm{kPa}$ ( 50 torr). When interviewed a week after surgery, amnesia was complete in all patients.

\section{Discussion}

Oxygen and $100 \mu \mathrm{g} \cdot \mathrm{kg}^{-1}$ of fentanyl is an acceptable form of anaesthesia, providing stable indices of oxygen demand during induction of 
anaesthesia, tracheal intubation and initial surgical stimulation in patients undergoing aortocoronary bypass surgery.

No significant changes in heart rate from control were noted throughout the course of the study. This is in contrast to Prakash, et al. ${ }^{14}$ and Waller, et al., ${ }^{4}$ who showed increases in heart rate after tracheal intubation, skin incision and sternotomy with fentanyl $15 \mu \mathrm{g} \cdot \mathrm{kg}^{-1}$ and $50 \mu \mathrm{g} \cdot \mathrm{kg}^{-1}$ respectively and Stanley, et al., ${ }^{1,2}$ who demonstrated a decrease in heart rate after fentanyl $20 \mu \mathrm{g} \cdot \mathrm{kg}^{-1}$ but no further change with intubation and initial surgical stimulation.

There are several reasons for the differences between these findings. Firstly, our patients received propranolol (mean dose $232 \mathrm{mg}$ per day) up to and including the day of operation, their last dose being 90 minutes before induction of anaesthesia. This maintenance of propranolol therapy has been shown to be an important factor contributing to cardiovascular stability during anaesthesia. ${ }^{9.10}$ Secondly, each patient in our series received fentanyl $100 \mu \mathrm{g} \cdot \mathrm{kg}^{-1}$, which is twice the dose given by Waller, et al. ${ }^{4}$ Thirdly, we administered pancuronium $0.1 \mathrm{mg} \cdot \mathrm{kg}^{-1}$ as soon as the patient failed to respond to verbal command. Other studies 1.2.4.8 used succinylcholine to achieve paralysis, a drug which might accentuate rather than oppose bradycardia induced by fentanyl. ${ }^{15}$.

Systolic blood pressure remained constant throughout the study apart from a significant 17 per cent fall from control after fentanyl 50 $\mu \mathrm{g} \cdot \mathrm{kg}^{-1}$, which is comparable to other reports. ${ }^{2.8}$ Part of this fall may be due to the hypertensive patients becoming normotensive on induction of anaesthesia. ${ }^{16}$ It may also be due to sudden withdrawal of a high resting awake sympathetic tone in anxious patients ${ }^{17}$ or to a weak alphablocking effect of fentanyl on vascular smooth muscle, as shown in vitro. ${ }^{18}$ Relative stability in systolic blood pressure and heart rate with fentanyl $100 \mu \mathrm{g} \cdot \mathrm{kg}^{-1}$ does not imply that patients in cardiogenic or haemorrhagic shock can safely tolerate these high doses of fentanyl. We have observed two patients, one in cardiogenic shock and one in haemorrhagic shock, who became severely hypotensive when given fentanyl 15 $\mu \mathrm{g} \cdot \mathrm{kg}^{-1}$. Neither patient is included in this study.

The relative stability in heart rate and systolic blood pressure with oxygen and high-doses of fentanyl is in contrast to tachycardia and hypertension which has been reported at the time of intubation with a thiopentone-nitrous oxide- halothane technique. ${ }^{9}$ However, in some patients, systolic blood pressure increased after the termination of the study upon sternal retraction or aortic root dissection. This may have been due to inadequate plasma levels of fentanyl as a consequence of the redistribution ${ }^{8,19,20}$ or simply due to inadequate dosage. It should be remembered that this technique was initially described in patients undergoing mitral valve replacement ${ }^{1}$ and then extended to include patients with ischaemic heart disease undergoing aortocoronary bypass surgery. ${ }^{2,8}$ It may be that this different patient population needs a much greater total dose of fentanyl, which has yet to be determined, to achieve stable haemodynamic parameters throughout surgery. Any increase in systolic blood pressure after the termination of the study was easily controlled by the addition of nitrous oxide or a nitroglycerin infusion.

The rate pressure product has been proposed as an index of myocardial oxygen consumption in both the awake patient ${ }^{21}$ and during anaesthesia $^{22}$ but, nevertheless, concern has been expressed as to its value. ${ }^{23.24}$ In this study rate pressure product was well maintained, only decreasing significantly below control values after sternotomy. In view of the consistency of the heart rate and systolic blood pressure, we believe that the stability of RPP cannot be considered misleading. ${ }^{23,24}$

It has been demonstrated both in vivo and in vitro that the plasma levels of fentanyl needed to depress myocardial contractility are far greater than those achieved in clinical practice. ${ }^{25-28} \mathrm{No}$ measurement of contractility was made in the present study, but it can be seen that, from a consideration of the Frank-Starling curve adapted for clinical practice, ${ }^{29}$ decreases in left ventricular stroke work index, stroke index and cardiac index closely parallel the decrease in pulmonary capillary wedge pressure. However, part of the decrease in cardiac index might be related to reduction of $\mathrm{Pa}_{\mathrm{CO}_{2}}$ from a mean of $5.95 \mathrm{kPa}$ (44.7 torr) to a mean of $4.8 \mathrm{kPa}$ (36 torr). ${ }^{13}$ Moreover, although no significant changes in systemic vascular resistance were demonstrated, there was nevertheless a trend for it to increase after surgical stimulation when cardiac index was decreasing.

The reason for the significant decrease in pulmonary capillary wedge pressure after completion of fentanyl infusion and maintained after skin incision and sternotomy is unclear. It does not appear to be related to institution of intermit- 
tent positive pressure ventilation, nor to increased systemic venous capacitance, since central venous pressure is unaltered.

The occurrence of chest wall rigidity ${ }^{6}$ was not a problem because of the prompt administration of pancuronium as soon as the patient failed to respond to verbal command. This is substantiated by the lack of increase of $\mathrm{Pa}_{\mathrm{CO}_{2}}$ before intubation.

The drug was infused through the side arm of a Cordis ${ }^{\circledR}$ Swan Ganz catheter introducer to avoid the high incidence of peripheral thrombophlebitis which, in our experience, follows infusion of high doses of fentanyl into peripheral veins.

The incidence of postoperative ventilation cannot be compared to other series ${ }^{2.8}$ since it is our policy to keep the patients intubated and ventilated until the morning after operation. No intraoperative awareness was encountered in this series; however, the overall incidence of recall with this technique is around one per cent in our institution. This low figure may be due to the large doses of fentanyl and/or its association with the diazepam and scopolamine premedication. ${ }^{31}$

Maintenance of beta blockade up to the time of operation, heavy premedication and fentanyl $100 \mu \mathrm{g} \cdot \mathrm{kg}^{-1}$ given rapidly produced significant haemodynamic changes during induction of anaesthesia and initial surgical stimulation in patients undergoing aorto-coronary bypass surgery. However, the indices of myocardial oxygen demand were stable.

\section{REFERENCES}

1. Stanley, T.H. \& Webster, L.R. Anesthetic requirements and cardiovascular effects of fentanyl-oxygen and fentanyl-diazepam-oxygen anesthesia in man. Anesth. Analg. 57: 411 (1978).

2. Stanley, T.H., Philbin, D.M. \& Coggins, C.H. Fentanyl-oxygen anesthesia for coronary artery surgery: cardiovascular and antidiuretic hormone responses. Canad. Anaesth. Soc. J. 26: 168 (1979).

3. Stanley, T.H., Berman, L., Green, O., RobERTSON, D.H. \& ROIZEN, M. Fentanyl-oxygen anesthesia for coronary artery surgery: plasma catecholamine and cortisol responses. Anesthesiology 5I: $\$ 139$ (1979)

4. Waller, J.L., Hug, C.C., Nagle, O.O. \& Craver, J.M. Fentanyl-oxygen anesthesia and coronary bypass surgery. (Abstract). International Anesthesia Research Society, 54th Congress, Reno, Nevada, March, 1980: 127-128.

5. De Castro, J., Parmentier, P. \& andrieu, $S$ Les limites de l'anesthésie analgésique pure. Ann. Anesth. Franç. 17: 1071 (1976).

6. Comstock, M.K., Scamman, F.L., Carter, J.G., Moyers, J.R. \& Stevens, W.C. Rigidity and hypercarbia on fentanyl-oxygen induction. Anesthesiology 51: S28 (1979).
7. Lowenstein, E. Morphine anesthesia-a perspective. Anesthesiology 35: 563 (1971).

8. Lunn, J.K., Stanley, T.H., Eisele, J., WebSTER, L. \& Woodward, A. High dose fentanyl anesthesia for coronary artery surgery: plasma fentanyl concentrations and influence of nitrous oxide on cardiovascular responses. Anesth. Analg. 58: 390 (1979)

9. Kopriva, C.J., Brown, A.C.D. \& Pappas, G. Hemodynamics during general anesthesia in patients receiving propranolol. Anesthesiology $48: 28$ (1978).

10. OKa, Y., Frishman, W., Becker, R.M., Kadish, A., Strom, J., Matsumoto, M., Orkin, L. \& Frater, R. Beta-adrenoceptor blockade and coronary artery surgery. Am. Heart J. 99: 225 (1980).

11. Kaplan, J.A. \& KING, S.B. The precordial electrocardiographic lead $\left(V_{5}\right)$ in patients who have coronary artery disease. Anesthesiology 45: 570 (1976).

12. Bain, J.A. \& Spoerel, W.E. A streamlined anaesthetic system Canad. Anaesth. Soc. J. 19: 426 (1972).

13. Suter, P.M. L'hémodynamique chez le patient sous ventilation mécanique. Schweiz, med. Wschr. 110: 61 (1980).

14. Prakash, O., Verdouw, P.D., de Jong, J.W., MeiJ, S.H., Van Der Borden, S.G., Dhasmana, K.M. \& SaXena, P.R. Hemodynamic and biochemical variables after induction of anaesthesia with fentanyl and nitrous oxide in patients undergoing coronary artery bypass surgery. Canad. Anaesth. Soc. J. 27: 223 (1980).

15. Reitan, J.A., Stengert, K.B., Wymore, M.L. \& MARTUCCI, R,W. Central vagal control of fentanyl induced bradycardia during halothane anesthesia. Anesth. Analg. 57: 31 (1978).

16. Prys-Roberts, C., Meloche, R. \& Foex, P. Studies of anaesthesia in relation to hypertension. Cardiovascular responses of treated and untreated patients. Brit. J. Anaesth. 43: 122 (1971).

17. Waller, J.L., Kaplan, J.A. \& Jones, E.L. Anesthesia for coronary revascularization. In: Cardiac Anesthesia, 1st ed. Kaplan, J.A. ed. New York: Grune \& Stratton (1979).

18. TODA, N. \& Hatano, Y. Alpha-adrenergic blocking action of fentanyl on the isolated aorta of the rabbit. Anesthesiology 46: 411 (1977).

19. Hug, C.C. JR. \& MURPhY, M.R. Termination of fentanyl actions by redistribution. (Abstract). The Pharmacologist 2l: 207 (1979).

20. McClain, D.A. \& Hug, C.C. JR. Fentanyl pharmacokinetics in man. Anesthesiology 51: S29 (1979).

21. Robinson, B.F. Relation of heart rate and systolic blood pressure to the onset of pain in angina pectoris. Circulation 35: 1073 (1967).

22. KaPlan, J.A. Hemodynamic monitoring. In: Cardiac Anesthesia, 1st ed. Kaplan J.A. ed., New York: Grune \& Stratton: 109 (1979).

23. Kissin, I., Reves, J.G. \& Mardis, M. Is the rate-pressure product a misleading guide? Anesthesiology $52: 373$ (1980).

24. Barash, P.G. \& Kopriva, C.J. The rate-pressure product in clinical anesthesia: boon or bane? Anesth. Analg. 59: 229 (1980).

25. Freye, E. Cardiovascular effects of high dosages 
of fentanyl, meperidine, and naloxone in dogs. Anesth. Analg. 53: 40 (1974).

26. De Castro, J., Van De Water, A., Wouters, L., Xhonneux, R., Reneman, R. \& Kay, B. Comparative study of cardiovascular neurological and metabolic side-effects of eight narcotics in dogs. Act. Anesth. Belg. 30: 12 (1979).

27. Strauer, B.E. Contractile responses to morphine, piritramide, meperidine, and fentanyl: a comparative study of effects on the isolated ventricular myocardium. Anesthesiology 37: 304 (1972).

28. Hug, C.C. JR. Pharmacology - Anesthetic drugs. Cardiac Anesthesia, Ist ed. Kaphan, J.A. ed. New York: Grune \& Stratton: 24 (1979).
29. Barash, P.G., Chen, Y., Kitahata, L.M. \& Kopriva, C.J. The hemodynamic tracking system: a method of data management and guide for cardiovascular therapy. Anesth. Analg. 59: 169 (1980).

30. Prys-Roberts, C., Kelman, G.R., Greenbaum, R. \& RoBinson, R.H. Circulatory influences of artificial ventilation during nitrous oxide anaesthesia in man. Results: the relative influence of mean intrathoracic pressure and arterial carbon dioxide tension. Brit. J. Anaesth. 39: 533 (1967).

31. Frumin, M.J., Herekar, V.R. \& Jarvik, M.E. Amnesic actions of diazepam and scopolamine in man. Anesthesiology 45: 406 (1976).

\section{RÉSUMÉ}

Les auteurs ont étudié les effets d'une anesthésie au fentanyl-oxygène chez dix patients soumis à un pontage aorto-coronarien. La dose totale de fentanyl administrée était de $100 \mu \mathrm{g} \cdot \mathrm{kg}^{-1} ;$ l'étude portait sur la phase d'induction et le début de la stimulation chirurgicale. Les dix patients étaient sous propranolol et nitrates et cette médication a été conservée jusqu'à la chirurgie. En prémédication, le diazépam par voie orale $\left(0.5 \mathrm{mg} \cdot \mathrm{kg}^{-1}\right)$ était suivi d'une injection intramusculaire de morphine $\left(0.15 \mathrm{mg} \cdot \mathrm{kg}^{-1}\right)$ et de scopalamine à la dose de $0.4 \mathrm{mg}$. Après installation, sous anesthésie locale, des cathéters veineux et artériels, ainsi que d'un cathéter de Swan Ganz on effectuait la mesure des paramètres suivants: fréquence cardiaque, pression artérielle systolique, pression capillaire bloquée, index d'éjection, index cardiaque, index de travail d'éjection ventriculaire gauche, résistance vasculaire périphérique, produit pression-fréquence, triple index, $\mathrm{Pa}_{\mathrm{O}_{2}}$ et $\mathrm{Pa}_{\mathrm{co}}$. Les mêmes mesures étaient reprises après administration de $50 \mu \mathrm{g} \cdot \mathrm{kg}^{-1}$ de fentanyl et de pancuronium, après l'intubation, après une seconde administration de $50 \mu \mathrm{g} \cdot \mathrm{kg}^{-1}$ de fentanyl, après l'incision cutanée et après la sternotomie.

On n'a pas observé de modifications significatives de la fréquence cardiaque, de la pression veineuse centrale, ni de la résistance vasculaire périphérique. La pression artérielle systolique et l'index de travail d'éjection du ventricule gauche diminuaient de façon significative après l'injection de $50 \mu \mathrm{g} \cdot \mathrm{kg}^{-1}$ de fentanyl, ce dernier demeurant abaissé pour le reste de l'étude. La pression de wedge, le triple index et la $\mathrm{Pa}_{\mathrm{CO}_{2}}$ diminuaient de façon significative après l'administration de la dose totale de fentanyl $\left(100 \mu \mathrm{g} \cdot \mathrm{kg}^{-1}\right)$, après l'incision de la peau et la sternotomie. On a noté des diminutions significatives du produit pressionfréquence après l'incision cutanée, de l'index d'éjection après la sternotomie et de l'index cardiaque après l'incision cutanée et la sternotomie.

Une anesthésie au fentanyl-oxygène aux doses de $100 \mu \mathrm{g} \cdot \mathrm{kg}^{-1}$ a permis d'obtenir des indices de consommation d'oxygène ventriculaire stables durant l'induction de l'anesthésie et le début de la stimulation chirurgicale chez des malades soumis à un pontage aortocoronarien. 